\title{
IV
}

\section{The Standards and Mechanics}

\section{of Security Clearance}

CO LONG as war is thought to be just around the corner, $\checkmark$ every great nation devotes a large part of its wealth and ingenuity to efficient military preparations. In so far as those preparations may involve the development of weapons or equipment, the United States, like other countries, will seek to conceal progress from the eyes of potential enemies in order to maintain the advantage that inventive skill may temporarily give it. Moreover, since the element of surprise is itself deemed a military asset, not only the details of mechanisms but also the extent of their availability may sometimes be regarded as "military secrets," to be withheld from the knowledge of competitors if possible.

Today, as earlier discussion has emphasized, the scientist is the nation's armorer to an extent never before approximated. $\mathrm{He}$ is himself the creator rather than merely the guardian of military secrets. Some part of his information must be available to all if civilization is to progress. Other bits of his knowledge may justifiably be buried for short-range military reasons. The dividing line is not hard and fast. The tug and pull of competing considerations will influence the pattern. Somehow, nevertheless, a pattern will emerge. The line is drawn, 


\section{SECURITY CLEARANCE}

uncertain in direction, fluctuating in purpose, and unstable in duration though it may be. Once it has been drawn, it momentarily determines the dimensions of the area of secrecy. And once that area has been defined by appropriate public authority, there immediately arises a proper interest in assuring that all who work within it will scrupulously observe its boundaries. So long as the boundaries exist, they must not be ignored.

Obedience to public commands is conventionally compelled by penalties upon the disobedient. The fear of detection and punishment deters transgressions. But, as daily sensations remind us, the threat of retribution does not wholly eliminate criminal or other antisocial conduct. At best, misbehavior is merely somewhat diminished. Hence society appropriately seeks for other measures, and especially measures of a preventive character, to forestall injuries to it. In the context of the present discussion, the measure chiefly relied on as a preventive of unreliability within the zone of secrecy is the personnel security program. Through this program the government hopes to sift out the persons who, like the faithless English scientists Alan Nunn May and Klaus Fuchs, might flout restraints which national military needs have generated. Excluding potential malefactors from the area of secrecy may be a surer shield than would be the most severe punishment of wrongdoing after the event. Since the world includes persons who are undisciplined or corrupt or treacherous, there is wisdom in trying to identify them before they are permitted to deal with matters of immediately vital public safety.

The prime purpose of the personnel security program is to assure that acts of sabotage will not occur and that "secret information" will not pass into the hands of others than those to whom it has been entrusted. Thus justified, the program extends to many types of personnel besides scientific workers. The construction gangs that erect the specially designed build- 
ings of an atomic energy installation, for example, must be "cleared," as must the maintenance employees, the clerical staff, the guards, and all the others whose jobs involve physical access to restricted areas or use of "restricted data." Similarly the businessmen who wish to bid on contracts to supply certain types of military equipment must be "cleared" before they may read the specifications that will shape their bids; and when a contract is awarded, the process engineers and other technicians, as well as many production workers who are involved in executing it, must be investigated and their "security" established to the satisfaction of public authorities.

A significant qualitative difference does, however, set apart the security investigations of scientists.

In the generality of cases affecting nonprofessional employees the investigators are chiefly concerned with the character of the individual under investigation. Does his past record suggest irresponsibility or inattention to regulations governing his employment? Is he a drunkard who might carelessly reveal confidences? Is he constantly in debt and therefore perhaps susceptible to bribery? Is his an abnormal personality? Does he have a serious criminal record that indicates habitual disregard of obligations to society?

The cases in which a scientist's security has been questioned are in marked contrast. In scarcely a single case involving a scientist, so far as diligent inquiry has disclosed, have the issues been of this sort. The scientists' cases have involved not character, but attitudes; not behavior, but associations; not personality, but opinion.

"Reliability" in these respects is chiefly the concern of the Atomic Energy Commission and the military services. The scope of their authority and the procedures they employ warrant consideration. 


\section{Personnel Security in the Atomic Energy Commission}

The Atomic Energy Act of 1946 emphasizes in many of its sections the policy of hoarding our real or supposed "atomic secrets." As a specific safeguard against revealing these treasures to individuals who might be unworthy of trust, the Act provides that-

1. No individual employed by a contractor or licensee having relations with the AEC may be permitted by his employer "to have access to restricted data until the Federal Bureau of Investigation shall have made an investigation and report to the Commission on the character, associations and loyalty of such individual and the Commission shall have determined that permitting such person to have access to restricted data will not endanger the common defense or security"; and

2. With exceptions not now material, "no individual shall be employed by the Commission until the Federal Bureau of Investigation shall have made an investigation and report to the Commission on the character, associations, and loyalty of such individual."

Thus the Atomic Energy Commission is empowered and directed to pass on the eligibility of all who find "restricted data" essential to performance of their scientific duties. In the main these are not scientists who are themselves a part of the AEC staff. The AEC directly employs no more than a hundred scientists, chiefly in administrative rather than research activities. The scientific work that interests the AEC goes forward in university or industrial laboratories or in huge installations that are owned by the AEC but operated by a contractor. The Carbide and Carbon Chemicals Corporation, for example, administers the gigantic plants and 
laboratories in Oak Ridge, and most of the scientists who work there are its employees, not the Government's. Similarly, the weapons research carried on by scientists at Los Alamos is one of the contractual responsibilities of the University of California, which also operates the Radiation Laboratory in Berkeley. So with each of the major centers of work in the field of atomic energy; the laboratories may have been created by the United States, but they are administered by academic or industrial contractors, which hire their own scientific staffs, subject always to the Commission's granting "security clearance" that will permit access to restricted data. When we speak of atomic energy scientists, therefore, we refer for the most part to the faculties of numerous educational institutions; or to the employees of such concerns as Monsanto Chemical Company, the operator of an AEC laboratory at Miamisburg, Ohio, where highly classified process, research, and development work is carried out; or to the staffs of installations like the Argonne National Laboratory, which is operated by the University of Chicago as chief contractor aided by a council of thirty other institutions. The various possible extensions of the program into private employment are readily suggested by the names of the corporations which, being interested in industrial applications of nuclear energy, support the University of Chicago's basic atomic and metals research:

Aluminum Company of America, American Tobacco Company, Beech-Nut Packing Company, Bethlehem Steel Company, Celanese Corporation of America, Commonwealth Edison Company, Copper \& Brass Research Association, Crane Company, E. I. du Pont de Nemours \& Company, Fairchild Engine \& Airplane Corporation, Inland Steel Company, International Harvester Company, Pittsburgh Plate Glass Company, Procter \& Gamble Company, Reynolds Metals Company, Shell Development Company, 
Standard Oil Company (Indiana), Standard Oil Development Company, Sun Oil Company, United States Steel Corporation, and Westinghouse Electric Corporation.

The AEC's duty to consider the reliability of many thousands of individual employees has not been an easy one. Between January 1, 1947, and April 28, 1949, the Commission occupied itself with security matters at $15^{1}$ of its 262 formal meetings, and spent perhaps a third of its entire meeting time on personnel security matters alone. ${ }^{1}$

The Commission inherited a large operation from the Army, which had administered the atomic energy program during its fast-growing infancy. The Army's security procedures had been, to put the matter as mildly as possible, somewhat primitive. Investigations of all employees were made under the direction of Military Intelligence. Those who were suspect were rather abruptly ejected. A man who was subject to being called into military service might find himself hurriedly summoned to leave his scientific researches and to enter forthwith upon less onerous duties in some military outpost. Those who could not be transferred in this way were simply dismissed summarily. Some of the quick decisions in that period were no doubt sound. Some probably were not. There simply was no time to be sure which was which, and war always causes casualties.

In most cases, of course, security clearance was not denied the scientists who were equipped to participate in the program. After all, a large organization was needed, and needed urgently. If every doubt were resolved against every employee, too many might have been ushered out; and there was no time in which effective replacements could be trained. As General William J. Donovan, the wartime head of the Office of Strategic Services, once remarked, "You can have an organization that is so secure it does nothing," or you can decide to move 
forward by taking some chances. "If you're afraid of wolves," he added, "you have to stay out of the forest." ${ }^{2}$ By and large the Army's Manhattan Engineer District was not afraid of wolves. It granted clearances.

When the AEC took over the MED's operations and its staffs, however, Congress directed that all who remained in work involving access to restricted data must be reinvestigated. To be sure, they were given interim clearance; but continuation of their employment rested on the AEC's finding, after a fresh investigation by the Federal Bureau of Investigation, that the common defense or security would not be jeopardized by their presence on the projects. To this large number of persons who were to be reinvestigated and reappraised were added the thousands of new recruits who entered the rapidly expanding atomic energy field after the war. From January 1, 1947, to April 30, 1949, a total of 141,469 individuals were evaluated by the Atomic Energy Commission. During 1949 there arose a total of 37,561 new personnel clearance cases, and this number may sharply increase as new installations come into being.

Obviously, a fairly elaborate administrative machine is needed to cope with a case load of these dimensions. The investigations themselves are not a burden to the Atomic Energy Commission, because they are conducted in each instance by agents of the Federal Bureau of Investigation. Contrary to a widely prevalent belief, however, the duty of evaluating the investigation reports rests on the AEC rather than the FBI, which is wholly without responsibility for reaching conclusions as to the significance of the facts and rumors its inquiries have revealed. The actual mechanics of decision are these:

1. The FBI report is first considered in a subunit of one of the AEC operations offices, which are located in Chicago, Hanford, New York, Oak Ridge, Santa Fe, Schenectady, and Arco, Idaho. Each of these offices has primary responsibility 
for certain of the activities and installations of the Commission. The initial review of the investigation report is undertaken by the office that has operational jurisdiction over the particular enterprise in which the affected individual will do his work. If, for example, a physicist were recruited for the Knolls Atomic Power Laboratory, administered by the General Electric Company in Schenectady, New York, his security clearance would first be considered by the staff of the manager of the operations office in that city; if he were to work in the atomic energy project of the University of Rochester, where research is done under contracts initiated by more than one AEC office, the papers would "follow the contract" and would accordingly go to the New York Operations Office or to Oak Ridge as the case might be; and if he were to be employed by the Monsanto Chemical Company in the Miamisburg laboratory in Ohio, the file would be studied by AEC officers under Oak Ridge direction.

2. At this stage the investigation reports are analyzed by members of the local security staff and, in difficult instances, by others, including legal counsel and the manager himself. If the analysts decide that "employing such persons or permitting them to have access to restricted data will not endanger the common defense or security," the manager (or his delegate) may grant the desired security clearance. Whenever doubts remain, and especially where certain particular types of evidence appear in the record, the whole file must be forwarded to the AEC's Division of Security in Washington. Despite indications to the contrary in some of the Commission's publications, the fact is that clearance may not be denied by the local Manager of Operations, though of course he may recommend that it should be withheld. In other words, the power to grant clearances has been largely decentralized, but the power to deny clearances has thus far been reserved in a central staff agency. The doubtful cases are considered at head- 
quarters by several strata of reviewers in the Division of Security, and the authoritative decision as to granting or withholding clearance is made there.

When clearance is denied, provision is made for subsequent review procedures, which may be briefly summarized as follows: If the affected individual is already employed under a prior clearance giving him access to restricted data, he receives notification that his clearance is about to be withdrawn. If he so desires, he may have a hearing before a "local personnel security board," appointed by the Manager of Directed Operations for the area in which he is employed. In most cases involving scientists, hearing boards thus far appointed have been composed of a member of the AEC administrative staff, an attorney of reputation in the locality, and a scientist who has insight into the relationship of the individual to the project as a whole. The local board so constituted makes a recommended decision to the local manager, who in turn forwards his recommendation to the Commission's General Manager in Washington. If this is adverse to the employee, he may request further consideration of the case by the Personnel Security Review Board, which may also be asked by the General Manager, on his own initiative, to review any case upon which he desires further advice. The Personnel Security Review Board has no power of final decision; its action is a recommendation to the General Manager to assist him in his final determination as to security clearance. The General Manager may, of course, present important policy considerations to the Commission itself.

The Commission has taken great care to appoint an advisory body that would command public confidence. The original Personnel Security Review Board consisted of Owen J. Roberts, former Supreme Court justice and now dean of the University of Pennsylvania Law School; Karl T. Compton, then the president of the Massachusetts Institute of Tech- 


\section{SECURITY CLEARANCE}

nology; Joseph C. Grew, former Undersecretary of State; George M. Humphrey, president of the M. A. Hanna Company; and H. W. Prentis, Jr., president of the Armstrong Cork Company. According to its minutes, that board met on seven occasions between July 1, 1947 and September $4,1948 .^{3}$ During this period some forty recommendations were made to the General Manager. The initial members of the Personnel Security Review Board tendered their resignation en masse during the summer of 1948 , and ceased functioning in September of that year. They were not replaced until March 10, 1949, when the AEC announced a "permanent Personnel Security Review Board" consisting of Charles Fahy, a Washington attorney and a former Solicitor General of the United States who had had broad governmental experience; Arthur S. Flemming, a former United States Civil Service Commissioner who is now president of Ohio Wesleyan University; and Bruce D. Smith, director of the United Corporation and formerly an official in the War Manpower Commission. More recently Mr. Fahy was appointed a judge of the federal Court of Appeals in the District of Columbia, his place on the review board being taken by Ganson Purcell, who practices law in Washington after having served as chairman of the Securities and Exchange Commission.

This impressive machinery for review and for possible modification of previous decisions works, however, only in the cases that involve "old hands," the people who have been cleared previously by the Manhattan Engineer District or by the AEC itself and who are still at work. Those who seek clearance now in order to commence scientific labors requiring access to classified data have no regularized means of obtaining review of an adverse determination. In their cases, if clearance is withheld, the matter is ended. No charges are stated, no hearing is held, no appeal is possible. Clearance is denied. At present this total absence of any formalized device 
to avoid unsound decisions affects many more people than does the presence of the Personnel Security Review Board. The failure to safeguard the rights of applicants for clearance is one of the most serious shortcomings of the AEC. The criticisms to which this deficiency gives rise are discussed more extensively in a later chapter.

From the very beginning of decentralization the AEC instructed its representatives in the field to make favorable decisions only in cases in which no "substantially derogatory information" had been brought to light concerning the applicant. "Substantially derogatory information" was but sketchily defined in the instructions which the AEC's staff received. ${ }^{4}$ Not until January 5, 1949, was the Commission able to formulate and announce the factors that may create serious doubts concerning eligibility for clearance. On that day it published its "Criteria for Determining Eligibility for Personnel Security Clearance." 5

Even these declared criteria are merely suggestive rather than definitive, for the Commission recognizes that no formula can embrace all the variants of human personality and organizational needs. Thus, for example, information that would probably raise doubts about the character of an unknown job seeker might be deemed wholly insignificant in the case of a man who had rendered long and satisfactory service in an atomic energy installation under the close observation of responsible supervisors. Moreover, as the Commission puts it, "a determination must be reached which gives due recognition to the favorable as well as unfavorable information concerning the individual and which balances the cost to the program of not having his services against any possible risks involved." This is a point of especially great importance in connection with the clearance of mature scientists. The number of trained persons is inadequate to supply the nation's present needs. If a scintilla of doubt about a man's reliability 
were to lead automatically to rejection of his potential contributions, we might indeed find ourselves with "an organization that is so secure it does nothing." For this reason the Commission's criteria have been set forth not as decisional principles, but as determinants of the categories of "derogatory information" which create serious doubts. The criteria do not foreclose the possibility that those doubts may be dissipated by other information; they merely serve to identify the cases which call for close attention.

"Category (A)," as set forth by the Commission, embodies types of derogatory information which, standing quite alone, establish a presumption of security risk. In any case of this sort the local manager has no power to resolve doubts in favor of clearance; the file must be at once forwarded to the Division of Security. The topics which Category (A) touches upon include information that the individual or his spouse has engaged in activities involving sabotage, espionage, treason, or sedition, or has had relations with foreign spies or "representatives of foreign nations whose interests may be inimical to the interests of the United States." So far as can be ascertained, information of this sort has been developed in very few if any of the nearly 200,000 cases upon which the Commission has now passed. Category (A) also includes:

1. Continued membership in an organization after the Attorney General has declared it to be subversive, or prior activities in a capacity which should have made the individual aware of its subversive purposes;

2. Advocacy of violent revolution;

3. Omission from or falsification of a Personnel Security Questionnaire or Personal History Statement;

4. Serious disregard of security regulations on former occasions;

5. Insanity; 
6. Conviction of felonies indicating habitual criminal tendencies; and

7. Addiction to excessive use of alcohol or drugs.

Apparently these types of seriously derogatory information are rarely disclosed by FBI investigation of persons seeking AEC employment. Members of the AEC staff at several locations have asserted that they know of no case of this sort in which a scientist has been involved. But since it has been impossible to obtain a central office confirmation of these field officers' impressions, one cannot say flatly that there never has been a Category (A) case. What can be confidently asserted, however, is that almost all the cases which have required thought before a decision was reached-and the total number of these is only slightly above two thousand-have arisen under "Category (B)." ${ }^{6}$

Category (B) like Category (A) lists matters that the Commission says would ordinarily warrant a denial of clearance. In these cases, however, the Manager of Operations is empowered to grant clearance if, on the whole record, he thinks it proper; he may recommend against clearance if he is convinced that the presumption of risk has not been overborne by other evidence; or in borderline cases he may pass the buck to the Director of Security in Washington without expressing a judgment one way or the other.

Category (B) cases include those in which either the individual or his spouse-

1. Has shown "sympathetic interest in totalitarian, fascist, communist, or other subversive ideologies";

2. Has been sympathetically associated with any members of the Communist Party or with "leading members" of any other organization the Attorney General has declared to be subversive;

3. Has been identified with a "front" organization when 
the individual's personal views "are sympathetic to or coincide with subversive "lines' ";

4. Has been identified as a part of or sympathetic to a group of subversives who are infiltrating a nonsubversive organization;

5. Has close relatives who live in countries which might exert pressures upon them as a means of forcing the individual to reveal sensitive information or commit sabotage;

6. Lives at the same premises or visits or frequently communicates with friends, relatives, or other persons who have subversive interests and associations;

7. Has formerly had close association with such friends, relatives, or others, now interrupted by distance but perhaps likely to be renewed in the future;

8. Has conscientious objection to military service when the objection is not clearly a product of religious conviction;

9. Has tendencies demonstrating inability to keep important matters confidential; carelessness in observing regulations concerning the use of restricted data; dishonesty; or homosexuality.

The chief differentiation between Category (A) and Category (B) is easy to see. Almost all the situations that fall in Category (A) are matters of personal conduct or character. Almost all the situations that fall in Category (B) are matters in the realm of ideas or associations which do not reveal any actual misconduct on the part of the individual.

This illuminates and emphasizes what is frequently overlooked in descriptions of the personnel security system. The finding that underlies a decision to withhold clearance need not be that the individual has been wicked or, even, that he probably will be wicked. All that is needed is a finding that 
the individual may be disposed to be wicked or careless at some indeterminately future time. In truth, all that is needed is a finding that the individual's spouse might designedly or otherwise acquire from him and subsequently transmit to others information that has not been released to the public at large.

Predictive or, if you will, precautionary findings of this sort involve very different mental processes from those that occur in the ordinary trial of an issue of fact. In most conventional fact-finding proceedings, an effort is made to achieve an evidential reconstruction of an event that has already occurred. In security proceedings the effort is, instead, to formulate a judgment about the degree of possibility that an event will occur in the future. The extent of the risk that a particular individual will be faithless is not subject to conclusive demonstration. A judgment concerning it involves hypotheses, impressions, experiences, and generalized prejudices (favorable or unfavorable to the applicant), which are brought to bear consciously or, often, unconsciously. It must be clear, therefore, that what is really being appraised in a personnel security case is not any particular question of fact but is, in a word, a man.

Nowhere is this more specifically recognized than in the AEC's "Memorandum of Decision Regarding Dr. F. P. Graham, December 18, 1948." Dr. Graham, later a United States Senator from North Carolina, was at that time president of the University of North Carolina. He was also the president of the Oak Ridge Institute of Nuclear Studies, a nonprofit organization of twenty-four southern universities established to assure broad regional participation in the atomic energy educational and training activities that center at Oak Ridge. To give the Institute effective guidance in its development Dr. Graham might occasionally require access to restricted information, and so he had to be "cleared." The FBI 
report on Dr. Graham that was laid before the AEC showed that he had "been associated at times with individuals or organizations influenced by motives or views of Communist derivation." Should clearance therefore be denied? The AEC in one of the two written opinions about personnel security that it has allowed to become public held that clearance should issue. " 'Associations' of course have a probative value in determining whether an individual is a good or bad security risk. But," concluded all five members of the Commission, "it must be recognized that it is the man himself the Commission is actually concerned with, that the associations are only evidentiary, and that common sense must be exercised in judging their significance. It does not appear that Dr. Graham ever associated with any such individuals or associations for improper purposes; on the contrary, the specific purposes for which he had these associations were in keeping with American traditions and principles. Moreover, from the entire record it is clear in Dr. Graham's case that such associations have neither impaired his integrity and independence, nor aroused in him the slightest sympathy for Communism or other anti-democratic or subversive doctrines."

So Dr. Graham was tried as a man, was found to be worthy of trust, and was cleared in order that the country might have the advantage of his continued participation in the atomic energy program.

Senator Graham, of course, is not typical of the men who may be involved in a security case. He was well known. His actions over many years were publicly recorded. The purposes of his associations were readily inferable from the course of his conduct in other connections. How can the Commission concern itself with "the man" instead of "the associations" in cases where the individual is less prominent and his motives less obvious? The procedures by which this is sought to be done will be examined in a later portion of this discussion. 


\section{Personnel Security in the Military Services}

Important though it is, the personnel security work of the AEC does not touch so many scientists and technologists as does the security program of the armed services. The latter, which may be called military clearance in order to distinguish it from the AEC processes just considered, applies to three large and wholly separate groups of scientific personnel.

In the first group are more than 12,000 scientists employed directly by the Army, the Navy, or the Air Force for work in installations like the Edgewood Arsenal, the Aeroballistics Facility, the Navy Electronics Laboratory, or the Alamogordo guided missiles project. The number of 12,00o includes only civilians with professional civil-service ratings as physical, biological, or agricultural scientists and thus excludes all military personnel who may also be assigned to scientific work.

In the second group are government scientists employed by civilian agencies but engaged in research on military projects. The National Bureau of Standards, a unit of the Department of Commerce, has, for example, undertaken for the Navy a study of the aerodynamic characteristics of aircraft bombs, finned projectiles, and rockets. Similarly the Bureau of Mines of the Department of the Interior has conducted on behalf of the Air Force an investigation of aviation fuels which might influence design of new engines and equipment. And the Tennessee Valley Authority, more or less as a by-product of its research on phosphatic, nitrogenous, and potassic fertilizers, has explored the adaptation of chemical products and processes to the manufacture of munitions. When projects of these sorts involve secret material, all those who may have access to the research data must be cleared even though they are the employees of other official branches of the Government. If the responsible military department withholds clear- 
ance of one of these federal scientists, he must simply be assigned to other work.

The third group, no doubt larger than the other two combined, comprises the scientific personnel employed by educational and other nonprofit institutions or by industrial corporations that have contracted to do classified work for one of the military agencies.

Because so much of the nation's developmental research and productive enterprise is linked with the making or improvement of military articles, the grasp of military clearance has extended far beyond the conventional boundaries of government into the realm of purely private employment. It is most important to note that the procurement agencies of the armed forces have exclusive and discretionary power to determine the extent to which work on contracts is to be classified. Since the military orders of our own government and our political allies absorb an ever-increasing share of American industry, a very large segment of all employment must quickly become subject to personnel security procedures unless the authority to impose classification restrictions is moderately exercised. Without reference to questions of organization or procedure, this prospect can but alarm all who value the American tradition of civilian freedom from military surveillance and restraint. The tendency to "overclassify" may have bitter consequences if not rigorously curbed.

Matters of principle aside, overclassification slows down vital production; when more and more persons must be cleared before work can be commenced, the end result is inefficiency. According to a dispatch by Walter $\mathrm{H}$. Waggoner to the New York Times on June 19, 1949, "Officials estimate that as many as 20,000 to 50,000 technicians, engineers, scientists and other key industrial employees either are not working or have only interim clearance on their jobs pending their 
specific approval for handling classified processes or materials. .. The mounting accumulation of security investigations to be made of industrial workers threatens not only to be a drag on important defense contracts that should be completed promptly, officials believe, but also to be a staggering administrative task for the National Military Establishment." Prominently listed among remedies that were being considered to reduce "the welter of investigations clogging the Government's security offices" were declassification of many processes and products and lowering the classification on others so that fewer persons would require clearance.

\section{Scientists Employed by the Military}

The Secretary of any one of the three military departments may remove any departmental employee whose dismissal he regards as "warranted by the demands of national security." This power, conferred by a statute that was enacted in 1942 "To expedite the prosecution of war," is summary and uncontrolled. ${ }^{7}$ The only procedural nicety the law prescribes is that "within thirty days after such removal any such person shall have an opportunity personally to appear before the official designated by the Secretary concerned and be fully informed of the reasons for such removal"; then he may submit "such statements or affidavits, or both, as he may desire to show why he should be retained and not removed."

As might be expected, this abrupt authority has been exercised brusquely on a number of occasions. It is to the credit of the armed services that they have sought to moderate their procedures. They have seriously attempted to avoid judgments that "demands of national security" require the degradation of professional men whose chief offense is nonconformism. Moderation and restraint are still needed.

Scientists who are employed by one of the military departments are, like all other federal employees, subject to 
removal under the terms of the "Loyalty Order," which will be considered in later pages. But "loyalty" and "security" may not be coextensive. If a man is thought to be disloyal, of course he is a "poor security risk." On the other hand, a man may be adjudged entirely loyal to his country and yet be deemed objectionable from the standpoint of security because he drinks excessively or his wife holds unorthodox opinions. The distinctions between, as well as the overlapping of, security and loyalty have caused organizational difficulties for the services that each of the three has attempted to surmount in a different way.

The Army's civilian employees, like all government personnel in civilian agencies, are first investigated by the Federal Bureau of Investigation. A supplemental investigation is also made by Military Intelligence. The initial determination that dismissal is warranted by security considerations is then made on the basis of the investigators' report supplemented by any material that may be available in intelligence files. In form the determination is a decentralized one, for the first decisive step is taken by the commanding officer of the area, advised by intelligence officers. He may suspend an employee up to ninety days, at the end of which period he must either reinstate the affected individual or recommend to the Secretary of the Army that he dismiss the man. This recommendation is in due time reviewed by the Intelligence Division, which passes it along to the Secretary's office with a statement of its findings and proposals. If the Secretary's Personnel Division agrees that charges should be pressed, they are sent to the employer with a letter of removal, which takes immediate effect.

There is always reason to fear too great a readiness to act adversely on very slight provocation in cases which involve unpopular elements and in which no opportunity is afforded to hear the other side of the story. Men who are "trigger happy" are unlikely to decide wisely in matters often marked by deli- 
cacy of nuance. Recognizing this, the Secretary of the Army in 1948 created a Security Review Board with a civilian chairman, to act as his adviser in these matters. Persons who have been summarily dismissed are afforded an opportunity to appeal to this body. Since every "loyalty case" may also be deemed a "security case" in a department that has authority to dismiss any employee summarily if security is involved, the Army does not observe the procedural and organizational aspects of the President's Loyalty Order; instead it proceeds in each instance under the powers conferred by Public Law 8o8, the $194^{2}$ summary removal statute. The Army's Security Review Board sits only in Washington, and is often only theoretically accessible to those who most urgently desire to appear before it. No funds are provided to make possible the attendance of the affected individual or his witnesses, so that many cases must be reviewed on the basis of documents and written protestations of innocence rather than on the basis of living evidence and arguments. Even so, the Security Review Board recommends to the Secretary that he set aside the decisions in about twenty per cent of all security dismissals, and in a still higher percentage of the cases that are appealed to it.

The Navy Department is even more summary in its acts under Public Law 8o8. If an employee "occupies a key position or a position of trust" (as many of the Navy's scientific personnel do), he may be removed on security grounds without any hearings whatsoever, whether in Washington or elsewhere, before or after the event. The employee receives a brief explanation of the reason for his having been ousted. Then, if he chooses, he may file with the Secretary a protest against the action. That is all, in theory. As a matter of fact, however, the Navy goes a good deal beyond this in providing procedures which, at least on the surface, are fairer and more orderly. Where the evidence raises a question about an employee's loyalty, a hearing is provided in the field, with an opportunity 
to seek review by the Navy Department Loyalty Appeal Board. An adverse determination by that body is subject to an appeal to the Civil Service Commission's Loyalty Review Board. Of course even if this board recommends the exoneration of the employee, the Secretary of the Navy still retains power to terminate the employment on the ground that "security" so demands. It is perhaps pertinent to note that the chairman of the Navy's appeal board, concerned with both "security" and "loyalty" cases, is the Department's director of personnel, who is generally regarded as the author of the law by which summary removal has been made possible.

The Department of the Air Force operates still differently. Acknowledging that there is a probable though not inevitable nexus between loyalty and security, it provides a single procedure for both types of cases. If a man is dismissed because the commanding officer deems him to be either a security risk or a disloyal person, he may ask for a hearing before a LoyaltySecurity Hearing Board. The hearing boards are decentralized, thus overcoming the geographical difficulty that impairs the utility of the Army's Security Review Board. But since the Loyalty-Security Hearing Board is drawn from local personnel, perhaps dominated in some instances by the tradition of subservience to the commanding officer whose judgment is formally under review, the blessing may not be altogether unmixed. It is noteworthy, however, that Air Force regulations require a majority of the hearing board's members to be chosen from civilian rather than military personnel.

If the local board's decision is adverse, there is in any event an opportunity for appeal to the Air Force Loyalty-Security Review Board, which sits centrally and is not affected by the same psychological pressures that may conceivably operate locally. Where the charge involves loyalty, there is yet another appeal, this time to the Civil Service Commission Loyalty Review Board. Let it be emphasized, though, that 
the Air Force like the Navy is not bound by a favorable judgment of the Loyalty Review Board. In the end, of course, a man may still be discharged because he is thought to be a security risk, even if the highest authority in the land were to adjudge him "loyal." Still, the Air Force does seem to go farther than the other two services in waiving the discretionary summariness with which Congress has endowed it.

Research and development programs are heavily relied upon by all three of the armed services as vital adjuncts to forces in being. As a report to the Army's General Staff forthrightly declared, "Success in any future war will depend as much on the effective use of all the scientific resources of the Nation as upon efficient industrial mobilization or skillful command of the fighting forces." ${ }^{8}$ It should therefore be a matter of profound national concern that personnel security, when arbitrarily administered, discourages participation in military research by the very men who can supply the talent so vitally needed. The case of Dr. X, a physiologist formerly at the Edgewood Arsenal, is illustrative.

Dr. X became a member of the staff at Edgewood in 1946 . At that time he had already established a reputation as an investigator of resourcefulness and high ability. For some years he had had an academic connection in which he had earned the respect of eminent colleagues. He had published some forty papers in the fields of physiology and biochemistry. During the war he participated in important studies, notably those having to do with motion sickness, under the auspices of the Committee on Medical Research, Office of Scientific Research and Development, and the Committee on Aviation Medicine of the National Research Council. Two months after Dr. X began his work at the Army Chemical Center he was curtly informed by a Military Intelligence officer that his clearance had been withdrawn; he was advised that he could resign forthwith "without prejudice" or, alternatively, he would be sus- 
pended and ultimately dismissed "with cause." At no time did he receive formal charges. A security officer, indeed, stressed that there were no charges, but that Dr. $\mathrm{X}$ was merely considered a "potential risk." This, he added conversationally, was because X's parents had been born abroad (though they had resided in this country at least since 1905 , when $\mathrm{X}$ was born in New York City); because he was a member of two nonscientific organizations (neither of which has ever been cited as a "communist front" by the Attorney General or even the House Committee on Un-American Activities); because, further, he had had contact with the late Brig. Gen. Evans F. Carlson, who had aided X's wartime experiments on fatigue and motion sickness, and also with members of the faculty at a leading institute of technology, with whom he had been professionally associated; and because, finally, in $194^{\circ}$ he had attended a lecture given in a university hall by a gentleman who was regarded by the security officer as a "fellow-traveler."

On this flimsy foundation, without hearing or official communication of any sort other than a formal notice of suspension, Dr. $\mathrm{X}$ was adjudged ineligible to do the work for which he had just been recruited. Five months later, after $\mathrm{X}$ had submitted a self-defensive statement and an impressive array of supporting affidavits, the Secretary of the Army ordered that Dr. X be reinstated with full pay. On November 12 he was recalled to duty. On November 13 he received his salary arrears. On November 14, having been vindicated, he resigned. Since then he has been a member of the staff of a privately endowed institute.

Apart from Dr. X's personal suffering, which must have been considerable, the episode has cost the Army the services of a man who had previously been willing and apparently able to advance its researches. "Rough and ready justice" in personnel security matters is functionally unsound. The rougher it becomes the less ready are we likely to be. 


\section{Scientists Employed Privately on Military Contracts}

Every contract to do research or manufacture for one of the military services contains a Secrecy Agreement. This binds the contractor to obtain written consent before he permits any alien to have access to drawings, specifications, models, and the like connected with execution of the contract. It also binds the contractor to bar the citizens in his employ from having access to any "top secret" or "secret" matters until the appropriate department gives its written consent. Employed citizens may be permitted access to "confidential" or "restricted" data without prior clearance, but this generalized consent may be withdrawn in particular cases if the military service so chooses. No distinction is made, organizationally or otherwise, between scientific personnel and any other class of nongovernmental employees.

In order to conserve manpower and to avoid conflicting decisions, the Army and Navy agreed early in 1942 that the former should execute the industrial personnel security programs on behalf of both services. When the Air Force was separated from the Army in 1947, its insistence upon an active share in administration caused a partial reconstruction of the machinery.

Under the present arrangements, an "army commander"that is, the commanding general of an area or of the Military District of Washington-is empowered in most instances to issue a "letter of consent" if, in the light of all the evidence presented to him, he is satisfied that the employment of the individual and his having access to classified information will not be "inimical to the interests of the United States." If he is in doubt, the file is forwarded to the Personnel Security Board, which is a tripartite body composed of commissioned officers representing the Departments of the Army, Navy, and Air Force. That board decides whether consent (clearance) 
shall be granted or denied. Its decision ultimately reaches the contractor in the form of a letter from the appropriate army commander or, in the case of the Air Force, from the Commanding General, Air Matériel Command.

At this time, if the decision is adverse, the affected individual is notified in writing that clearance has been withheld; and he is supposedly informed, also, concerning the ways in which he may request a further review of the case by the Industrial Employment Review Board. In numerous past instances, as Army officers have candidly acknowledged, notification of appellate procedures was carelessly omitted, though there has been recent improvement in this respect. Inattentiveness to this detail was no doubt attributable in large part to the rapid demobilization and reassignment of military personnel immediately after the war, which meant that inexperienced and partially trained men were given unaccustomed tasks. The matter is of considerable importance, because neither the existence nor the procedures of the Industrial Employment Review Board have been widely publicized nor, even, made matters of record in accessible documents. ${ }^{9}$

The IERB is wholly separate from the Personnel Security Board. Its members have had no contact with a case before it is docketed with them for review. At that time the appropriate files are moved from the Personnel Security Board to the IERB for a fresh examination. A denial of clearance is appealable by the individual concerned (who may be represented by counsel or by his labor union if he wishes) or by the contractor-employer.

The standards of judgment for determining whether access to classified information will be "inimical to the interests of the United States" have undergone an interesting process of elaboration in recent years.

During the war years a "Joint Memorandum on Removal of Subversives from National Defense Projects of Importance 
to Army or Navy Procurement" defined the term "subversive activity" as meaning merely "sabotage, espionage, or any other wilful activity intended to disrupt the national defense program."

In 1946 a new effort was made to clarify the services' thinking. Administrative instructions, over the signature of General Eisenhower as Chief of Staff, dealt with "Suspension of Subversives from Privately Operated Facilities of Importance to the Security of the Nation's Army and Navy Programs." These instructions emphasized that "No employee should be suspended as a result of idle rumor, normal labor activity, gossip, or anonymous communication, nor should an employee be suspended for any reason other than a reasonable suspicion that he is engaged in subversive activity." 10

But by 1948 the emphasis that had prevailed during the war and immediately afterward was shifted. No longer was there a focus on activity as an indication of possible subversiveness. Thenceforward the test of danger was to be "a reasonable belief that the individual involved has engaged in one or more of the following activities or associations . . " There then follow twelve topics, all but three of which refer to personal conduct (such as sabotage or encouragement of sedition) or characteristics (such as history of serious mental or emotional instability). The three that involve associations were stated as follows:

“(5) Affiliation with any organization or movement that seeks to alter our form of Government by unconstitutional means, or sympathetic association with any such organization, movement or members thereof;

“(6) Being influenced by or subject to the dictates of any foreign power to an extent detrimental to the interests of our Government or membership in any organization or movement so influenced by or dictated to; 


\section{SECURITY CLEARANCE}

“(7) Affiliation with any foreign or domestic totalitarian organization or movement or intimate or sympathetic association with any such organization, movement, or members thereof." 11

During the twelve months from July 1, 1946, to June 30, 1947, when the stress was on "subversive activities," the IERB considered only three cases. During the next twelve months, toward the end of which the change from "activities" to "associations" became formally operative, the board received twenty cases. In the next two months, July 1, 1948, to September 1, 1948, thirty new cases were filed with the IERB. During 1949 approximately 110 applications for review were acted upon. Possibly the increased case load is not caused wholly by the present concern with whom a man knows rather than what he does. But a former chairman of the IERB has revealed that virtually every matter which has come before the board since April 1948 has been an "associations" case.

This shift in emphasis is a direct reflection of the "Loyalty Order," which since 1947 has been used to test the eligibility of persons who desire employment in the federal service. On November 7, 1949, the Secretaries of the Army, Navy, and Air Force formalized the relationship by issuing a new set of "Criteria Governing Actions by the Industrial Employment Review Board." In the directions they then gave the Board, the Secretaries prescribed that access to classified information should be denied for virtually the same reasons as might throw doubt upon a public employee's loyalty. ${ }^{12}$

\section{The Composition of the IERB}

The Industrial Employment Review Board powerfully affects the status of private persons. It determines whether they may remain in employment for which their own employers deem them to be fitted by education, experience, and aptitude. 
It is of more than passing interest, therefore, to consider the structure of the tribunal.

Until the closing days of 1949 no civilian sat upon the Board whose decisions operated so directly upon civilians. All its members were military men without special training for adjudication. Four officers composed the administrative court, one voting member drawn from each military service and a nonvoting chairman who was detailed to that duty by the Provost Marshal General of the Army. The chairman, despite his inability to vote, was from the first the true director of the Board's operations. He organized the evidence, conducted the major portion of the questioning during hearings, and formulated the decisions that were reached. No member of the Board, not even the chairman, devoted full time to its work; each of the members except the chairman had as an alternate a brother officer who could sit in his stead when he was otherwise occupied.

The military cast of the Industrial Employment Review Board was strongly criticized during 1949 by the American Association for the Advancement of Science, the American Civil Liberties Union, and others. Partially in response to these promptings a significant change was initiated in December 1949. The IERB was removed from the Office of the Provost Marshal General of the Army. It has been reconstituted as a joint board of the Departments of the Army, Navy, and Air Force, responsible to the Secretaries of those departments rather than to a general officer. Its policies are to be framed or approved by the Munitions Board, a civilian agency within the Department of Defense, which, moreover, has been empowered to appoint a civilian as the IERB's chairman. The members of the IERB (and their alternates) other than the chairman are to be appointed by the respective military Secretaries and may be either officers or civilians. At least one member of the Board must now be a member of the bar. Three 
members of the Board constitute a quorum, but the lawyermember must be one of the three when a case is being finally decided.

The reorganization of the IERB in terms that give it a somewhat civilian rather than an exclusively military orientation is no reflection upon the officers who have previously staffed the tribunal. They have served conscientiously and, especially in the case of the successive chairmen appointed by the Provost Marshal General, have been reasonably aware that civil rights as well as military security are important to the nation. Occasionally there have been intimations of occupational attitudes that are perhaps irrelevant to the task at hand, as when the Army member in a belligerent and hectoring tone of voice demanded to know why a young scientist had not been in uniform during the war. When the young man mildly replied that his employer had sought his draft deferment because of the importance of the work he was then doing, the officer sneeringly snapped the question, "Nobody stopped you from enlisting, did they?" This sort of occurrence, however, has seemingly been rare; there has been little reason to challenge the Board's members for having blustered or having been willfully blind to favorable evidence. In more cases than not the Board has reversed the unfavorable action of the security officers and has directed that clearance be granted; according to one member of the IERB, it has learned that officers who spend a great deal of time in investigating charges of subversive associations "tend to develop fixations and only look at the bad side of the record." 13

Nevertheless, there is considerable ground for arguing against the further appointment of officers to sit on this tribunal. The IERB, as a body that determines the economic and social fate of civilians by adjudicating their professional or occupational opportunities, ought to be composed entirely of civilians, answerable to other civilians rather than in part 
to military superiors. The body is essentially a judicial one. Service upon it is not a very rewarding side-line activity for a professional soldier. No military knowledge is involved in its deliberations. Whether the material to which access is sought should be classified as "top secret" or "secret" or "confidential" is not a question before the Board. Appropriate officers of the National Military Establishment will already have considered that problem, and will have settled it authoritatively. The IERB concerns itself solely with the citizen's reputation and reliability. An issue of that sort is not within the specific and distinctive competence of the military. As a matter of important principle, members of the Industrial Employment Review Board should be selected from those who are not in the active service of the Army, the Navy, and the Air Force.

This principle is buttressed by one of our most deeply rooted national traditions. From the earliest days of the republic's existence, the American military has been subordinated to civil authority in other than strictly military affairs. Indeed, one of the grievances listed in the Declaration of Independence was that the British had exalted the military over civil power in the American colonies; the first constitutions of Delaware, Maryland, Massachusetts, North Carolina, Pennsylvania, and South Carolina specifically reversed the allocation of control by providing that civil authority should at all times prevail over the military. General Washington himself declined to try civilians before military tribunals until he received express authorizations from the Revolutionary Congress. And in later years the Supreme Court has held with great consistency that action by military authorities having impact upon private rights cannot be sustained merely on the ground that there is "military necessity" for them; only a danger that is "immediate and impending and not remote and contingent," or a specific Congressional authorization, can serve to blur 
"the boundaries between military and civilian power," which, the Supreme Court recently said, have "become part of our political philosophy and institutions." 14

This is not merely a matter of interest to legal antiquaries. The history of all the world shows that truly dominant militarism has grown out of the gradual and often even unintentional absorption by the army of state functions, and the performance by soldiers of duties for which military service provides no peculiarly useful equipment. Tribunals manned by officers whose profession is arms rather than justice have in the past produced bizarre conclusions arrived at after shocking procedures. ${ }^{15}$ It is praiseworthy that superintendence over the functions of the IERB has, by the recent reorganization, been committed to a civilian chairman before the true nature of those functions had become entirely obscured by reason of their having been too long performed by soldiers. The Secretaries of the military departments now have it within their power to supplant the remaining military members. Thus far they have shown no disposition to do so. All but the chairman of the Board are officers, while other officers serve as the tribunal's executive director and procedural adviser. Competent and disinterested as they no doubt are, they should now be replaced. Happily, no real or supposed threats to public order require abandoning fundamental procedures or reshuffling the division of power between civilian and military authorities in the United States. ${ }^{16}$

\section{Centralization of IERB Proceedings}

The Industrial Employment Review Board is not, from the standpoint of the individual involved in its proceedings, a true review or appellate body. It is, rather, the trial court. At no earlier point has the affected person had opportunity for interview or for hearing, whether formal or informal. At no earlier point, in fact, has he had even a generalized notice 
that his status is in question. When, therefore, he is advised that clearance has been denied by the commanding general (who, as we have seen, acts upon the advice of the Army-NavyAir Force Personnel Security Board), he turns to the IERB for the trial hearing he has not yet had.

In one important respect, however, the IERB is unlike other courts of first instance. When a trial court speaks, it renders a judgment which, ordinarily, is subject to review by some higher tribunal. Not so the Industrial Employment Review Board. It is not only the court of first resort. It is also the court of last resort. Its verdicts are final and unreviewable.

Few systems of law administration in modern society have failed to provide opportunity for correction of errors by the tribunal that first hears a case. The absence of such an opportunity in this instance is made more serious by the fact that the IERB sits exclusively in Washington. This centralization results, as a practical matter, in denial of hearings in many cases. The expense of attendance upon sessions in Washington effectively prevents appellants from presenting their defenses in person or through counsel of their own choice. Witnesses cannot be transported except at a cost that makes it unfeasible to offer their testimony. True, the chairman of the Board or one of its members occasionally leaves Washington in order to hear matters which have arisen at distant points. In no case within five hundred miles of Washington, however, has there been a chance to obtain a cheap and convenient hearing. And even when a Board member does "ride circuit," the appellant may still have long distances to travel before he reaches the assigned place of hearing. Once arrived, he faces only a single officer rather than the Board as a whole; the final decision is handed down by the Board in Washington on the basis of the stenographic transcript and the presiding officer's oral recommendation, which is undisclosed to the appellant and which he can do nothing to counter. 
A start has been made in overcoming these very real organizational difficulties. The new charter of the IERB permits the creation of regional or area boards, composed as is the central body and possessing the same measure of authority. As yet no regional boards have been created, and responsible officials have privately stated that none will be unless the present case load should unexpectedly increase. Plans are under way, however, to designate referees or trial examiners who will be able to conduct proceedings locally, not with a view to making decisions, but merely to permit a hearing to be held in a suitable place without intolerable expense to the appellant. It is not now contemplated that the referee will do more than take testimony. The resulting record will be forwarded to Washington for authoritative consideration by the IERB itself.

If these plans mature, they will make for improvement in the present situation. But they do not go quite far enough.

The first step must be to recognize the IERB for what it is, namely, a trial board rather than an appellate board, and then to replace it with a true review board to which unfavorable judgments may be appealed.

The second step must be to provide trial boards that will sit in or near the major industrial and educational centers of the country as occasion may arise. Only in that way can the opportunity for hearing become a practical reality in all cases, rather than a mere form of expression. Like the reconstituted review board, the trial boards should be composed of civilians; distinguished citizens could very probably be readily recruited for this part-time public service. A working model is at hand in the personnel security operations of the Atomic Energy Commission. There, it will be recalled, local boards hear the cases in the first instance, subject to later review by a central appellate body. The AEC model may be suggestive of one additional improvement in military security matters. 
In AEC cases involving a professional employee, a member of his profession sits on the trial board. This affords desirable assurance that the hearings will not ignore the bearing of the respondent's work on the whole project of which he is a part. A similar occupational representation in military security cases might reinforce sobriety of judgment and might encourage general confidence in the fairness of the proceedings. 